\title{
On the Determination of Aldosterone in a Small Amount of Various Biological Materials by Means of the Double Isotope Derivative Diltuion Method and Thin Layer Chromatography
}

\author{
Kazuo ISHIBASHI \\ Laboratory of Endocrinology \& Metabolism (Chief : Tatsuo Oda, M.D.) \\ 2nd Department of Internal Medicine (Director : Professor Kenzo Oshima, M.D.) \\ Nihon University School of Medicine, Itabashi, Tokyo, Japan
}

The theoretical basis for isotope derivative assays was developed by Udenfriend and his associates (1950) with the use of the labeled pipspyl compounds for the analysis of amino acid.

Bojesen (1956) used the labeled pipsyl derivatives to determine plasma cortisol. Avivi et al. (1956) attempted to use tritium and $\mathrm{C}^{14}$-labeled acetate derivatives for aassy of aldosterone. The experiment was theoretically correct but failed becaue of incomplete purification, low specific activity of the tritium tracer, and the use of peripheral plasma.

Then, Ayres (1961), Tait (1061), Jones (1959) used the labeled steroids to assay corticosteroids. The double isotope derivative procedure was investigated by Kliman and Peterson (1959). They used the paper chromatography to purify aldosterone and aldosterone diacetate. The procedure of paper chromartogaphy requires a complicated technique and is time consuming. Therefore, I have attempted to perform the isolation and determination of aldosterone by the method applying thin layer chromatography and double isotope derivative dilution assay.

1) Sampling and extraction (Fig. 1)

Urine samples for 24 hours of 3-5 rats were acidified to $\mathrm{pH} 1.0$ and allowed to stand for 24 hours at $20^{\circ} \mathrm{C}$. They were extracted five times with 0.2 vol. chloroform and the extracts were washed with 0.1 vol. $0.1 \mathrm{~N}$ sodium hydroxide and distilled water. The combined extracts were evaporated to dryness in vacuum. Adrenal venous blood samples of dogs by J. Yoshizawa's method were extracted two times with 0.2 vol. chloroform, and fat disconnected itself from the extracts.

The materials of rat's adrenals were incubated by Saffran's method and incubated medium were extracted two times with 0.5 vol. chloroform; $1 \cdot 2 \cdot \mathrm{H}^{3}$ aldosterone was added to each sample as an indicator before the extraction with chloroform. Following the extraction, the extracted materials were applied into the column chromatography.

II) Thin layer chromatography

The Yazawa (Japan) apparatus for thin layer chromatography was used, with Kieselgel-G (Merck) as absorbent. All the chromatographies were developed by the ascending techniques and the length of development was $10-14 \mathrm{~cm}$. The following solvent systems were used (Fig. 2): 
System A Ethyl acetate (90); chloroform (10); water (1)

System B Methanol (10); chloroform (90); water (1)

System D Benzene (50); acetone (59); water (2)

System E Methal (20); Benzene (80); water (1)

In order to check the purification of aldosterone, the U.V. absorption spectra and sulfuric acid chromogen spectra were examined. It was fully recognized that the spectra of aldosterone exactly coincided with that of reference standard (Fig. 3).

III) Acetylation and distribution (Fig. 4)

After the purification and isolation by T.L.C. (system A, B, D), the residues were transferred with a small volume of methanol to an acetylation tube, and the extracts were dried in $\mathrm{N}^{2}$ gas.

Anhydrous pyridine and $1 \cdot \mathrm{C}^{14}$ acetic anhydride were added to each tube, and the tubes were covered by stoppers very tightly. The samples were incubated for 24 hours at $37^{\circ} \mathrm{C}$. After acetylation, $2 \mathrm{ml}$ distilled water was added to each tube and left to stand for 1 hour. Then $5 \mathrm{ml}$ chloroform was added to each tube, and washed three times with $2 \mathrm{ml}$ distilled water, and the chloroform layer was taken in.

In oder to confirm the complete acetylation, the acetylation product was compared with pure aldosterone on Infra-Red-Spectra (Fig. 6).

This showed complete acetylation. After acetylation, residues were developed two times on T.L.C. (system A.E.).

$\mathrm{H}^{3} / \mathrm{C}^{14}$ ratio was constant $(10: 1)$ on two developments of T.L.C. Over-all recovery of this procedure was about $20 \%$.

\section{IV) Counting}

Phosphor reagent, $5 \mathrm{ml}$, was added to the dry residue and the samples were assayed for tritium and $\mathrm{C}^{14}$ in a liquid scintillation counter. Tritium quenching was highest in the sample of rat's urine.

\section{RESULTS (Tab. 1)}

The aldosterone excretion rate of normal rat's urine was $0.01-0.06 \mu \mathrm{g} / \mathrm{day}$. The range of aldosterone values of adrenal venous blood of normal dogs. was $0.013-0.018 \mathrm{~g} / \mathrm{ml}$. The aldosterone production values following the incubation of rat's adrenals were $0.205-$ $0.253 \mu \mathrm{g} / 100 \mathrm{mg}$. adrenal weight/12 hours.

\section{SUMMARY}

A new method using T.L.C. and double isotope derivative dilution assay for the determination of a small amount of aldosterone in various biological materials is reported. This method will be strongly recommended for its speediness, convenience and economy.

I wish to thank to Dr. Tatsuo Oda, Akio Ishii and Hideo Suzuki for the valuable suggestions and advices, and to Prof. Dr. Kenzo Oshima for his continuous encouragrement in this study.

(pp. 1248〜1253) 


\section{Double Isotope Derivative Dilution Method $ょ$ Thin Layer Chromatography による微量生体試料に於ける Aldosterone の定量法について}

日本大学医学部第二内科学教室（指導：大島研三教授）
石

(昭和41年11月 7 日受付)

緒論

Isotope derivative assay の理論は，1950年に Udenfriend ${ }^{1)}$ が， labeled pipsyl compounds を用い，ア ミノ酸を分析することによつて発展させた。

Steroid に関しては，1956年 Bojesen ${ }^{2}$ が labeled pipsyl derivative を用いて plasma cortisol を, 次い で同じく1956年に，Avivi ${ }^{3)}$ が $\mathrm{H}^{3}$-labeled acetate と $\mathrm{C}^{14}$-labeled acetate t用いて aldosterone の assay を試みている。しかし試料の純化が不完全であつたてと, tracer の specific activity が低く, かつ生体 試料として未梢血を使用した等の多くの問題点のため成功に至らなかつた。 その後更に Ayres ${ }^{4}(1957)$, Tait $^{5)}$ (1961)，Ulick ${ }^{6}$ (1961)， Jones ${ }^{7}$ (1959)等が labeled steroid を用いて steroid の assay を試みている. 1959年 Kliman \& Peterson ${ }^{8)}$ は， $\mathrm{H}^{3}$-labeled acetic anhydride と， $\mathrm{C}^{14}$-aldosterone diacetate を用いた double isotope derivative dilution method を考案した。乙れによると, 犬副腎静脈血中 aldosterone に ついては, $0.001 \mu \mathrm{g}$ 程度の定量が可能であると報告している。 なお彼等は corticoids 純化のため, paper chromatography を使用している。 しかし paper chromatographyは, 当教室の小田 ${ }^{9}$, 石井 ${ }^{10)}$ 経験から も，高度の熟練と長時間の展開を要するのが難点である。一方1965年当教室の鈴木 ${ }^{11}$ が発表した column chromatography と thin layer chromatography (以下 T.L.G) 存応用した方法は, 従来の paper chromatography に比し，その簡便さと卓越した分離能を示す点で生体試料からの aldosterone の分離定量に, 充分活用されるべき方法と考えられる。著者はこの T.L.C の有用性に着目し，更にてれに， $1 \cdot 2 \cdot \mathrm{H}^{3}$-aldosterone 及び 1-C ${ }^{14}$ acetic anhydride を用いた double isotope derivative dilution method を応用し, 微 量生体試料よりの aldosterone の分離定量にほぼ満足すべき結果を得たので報告する.

\section{実 験 方 法}

\section{i) Sampling 及び Extraction}

微量試料として rat 3〜 5匹の 24 時間尿，犬の副腎静脈血約 $5 \mathrm{cc}$, rat 1〜2匹の副腎を用いた。個々の sample そついての aldosterone の抽出方法の概略を次に述べる(Fig. 1).

即ち, rat 尿は $\mathrm{pH} 1.0$ 亿て24時間酸加水分解後, $1 / 5 \mathrm{vol}$. の chloroform にて 5 回抽出を行ない, 1/10

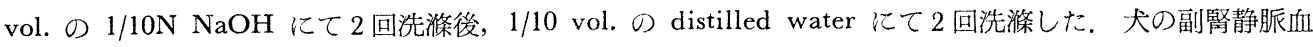
は当教室の吉沢 ${ }^{12}$ の方法にて約 $5 \mathrm{cc}$ を採血し，等量の distilled water にて溶血後， 1/5 vol. のchloroform にて 2 回抽出を行い，石油エーテルにて脱脂する. rat 副腎は断頭後直ちに摘出し, Krebs-Ringer Solution 中にて被膜を剥離した後 4 等分し, Saffran ${ }^{13)}$ の方法, 即ち $95 \% \mathrm{O}_{2}, 5 \% \mathrm{CO}_{2}$ を通気しながら $37^{\circ} \mathrm{C}$ 恒温槽中 にて振盪30分間 preincubate し，その後 medium を交換して 1 時間 incubate し，再度 medium を交換 して 1 時間 incubate した. 次いで incubate mediurn を $1 / 2 \mathrm{vol}$. の chloroform にて 2 回抽出後, 石油工

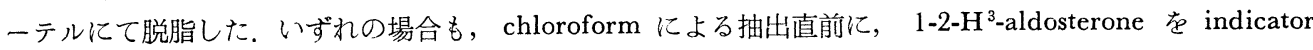
として加えた. 
Fig. 1. Double isotope derivative dilution assay of aldosterone in biological extracts

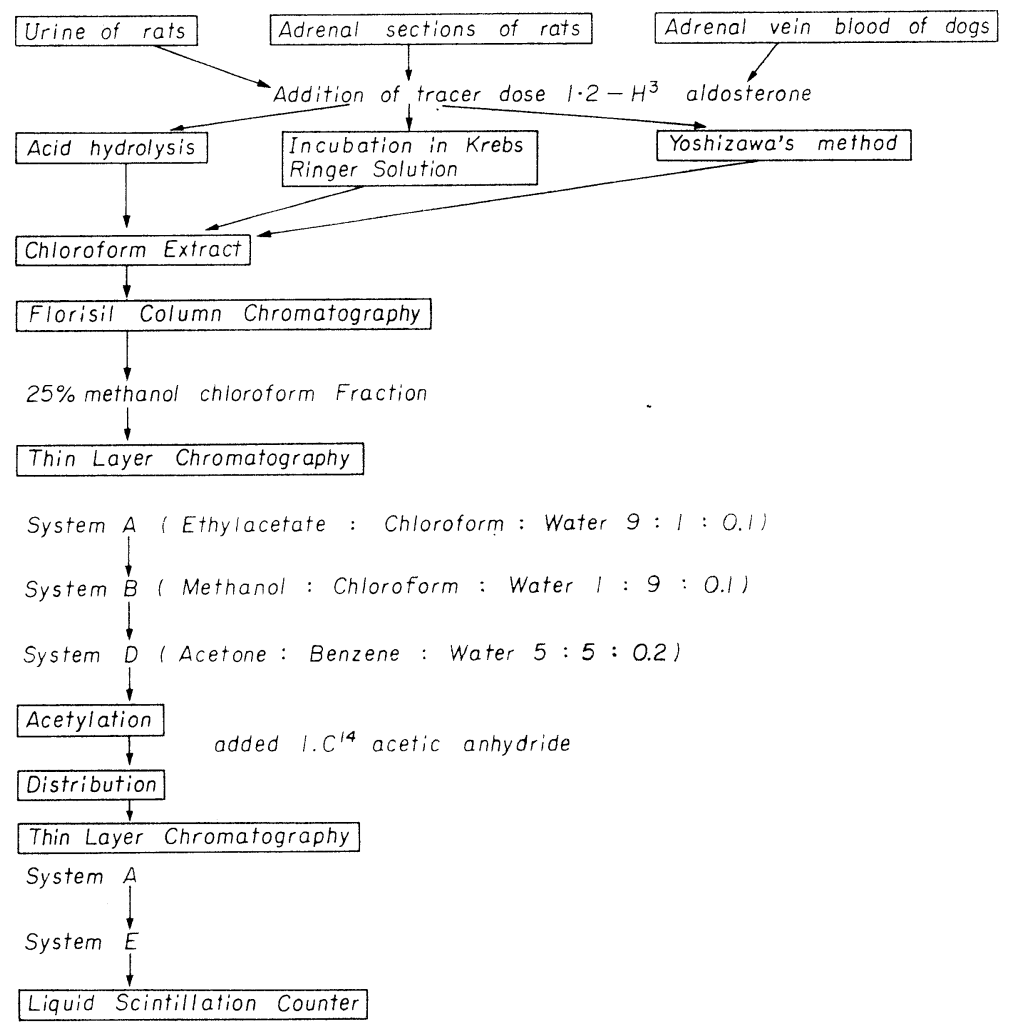

\section{ii) Purification}

以上の方法にて抽出した aldosterone を含む corticosteroids を，florisil column に吸着させ，その25\% methanol chloroform fraction を採取して蒸発乾固後, system A, B, D の3つの T.L.G に順次展開し, aldosterone の単離純化在企つた。兴の際使用した T.L.C の各 system に於ける free corticoids 及び tetrahydrocorticoids O位置は Fig. 2 に示す通りである。即ち aldosterone の system A 亿於ける Rf

Fig. 2. $\mathrm{Rf}$ values of free and tetrahydrocorticoids on T.L.C. in our systems

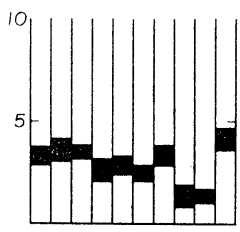

System $A$

Ethyl acetate : 90

chloroform : 10

water

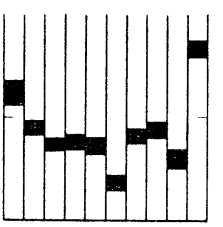

System $B$

Methanol : 10

Chloroform : 90

Water : 1

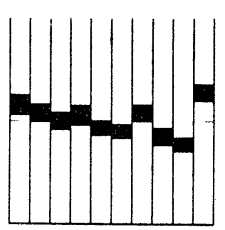

System D

Benzene : 50

Acetone : 50

water : 2

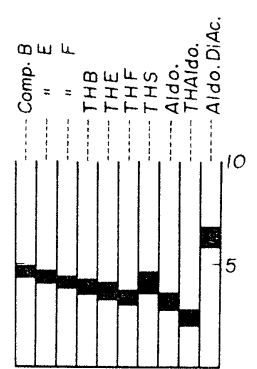

System $E$

Methanol : 20

Benzene : 80

water : 1 
Fig. 3. Comparisons of the U.V. absorption spectra. The samples extracted from the adrenal vein blood are eluted from the combined system $\mathrm{A}$ and $\mathrm{B}$.
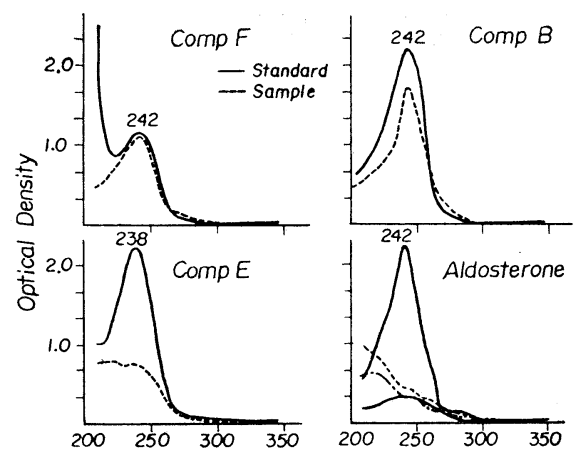

Fig. 3'. Comparisons of sulfuric acid absorption spectra of the same materials shown in Fig. 3

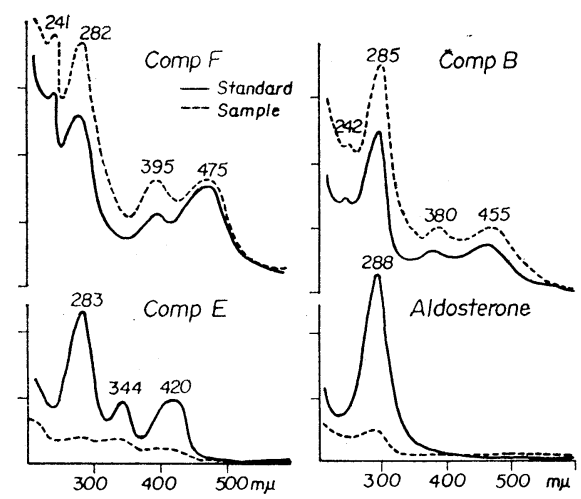

值は 0.15〜0.25, system B では 0.4〜0.46, system D では0.27〜0.35であつた. 尚 T.L.G. は, Kieselgel G を $250 \mu$ の薄層とし， 全て上行性に10〜 $13 \mathrm{~cm}$ 展開した。 Fig. 3，3' は以上の方法で純化単離して得た試 料の硫酸クロモーゲン吸収スペクトル及び紫外部吸収スペクトルを, 各 reference standard のそれと比較 したものである. Fig. 3，3' に示す如く，各試料の吸収スプクトルが, reference standard の吸収スペクト ルと極めて良く一致し，純化は満足すべき状態に達していると云えよう.

\section{iii) Acetylation 及び Distribution}

System A, B, D そて aldosterone を単離純化後, 乾渣を methanol にて acetylation tube に溶出し, 蒸発乾固後 1- $\mathrm{G}^{14}$ acetic anhydride 及び anhydrous pyridine $0.05 \mathrm{ml}$ を加え, silicagel blue を充填した 乾燥管にて密栓し，管壁を $5 \sim 6$ 回内容液にて洗涤し，室温にて一昼夜放置して acetylation を行つた. 次いで acetylation に加わらなかつた過剩の I-C (14 $^{14}$ acetic anhydride を除去するため，次の如き方法を用い た Fig. 4. 即ち, distilled water $2 \mathrm{ml}$ を加え, 30分放置して I-G-G-acetic anhydride を acetic acid とし た後, sodium bicarbonate を $\mathrm{CO}_{2}$ の気泡の出なくなる迄加え, Thermomixer にてよく攪找後, 1 時間室 温にて放置し；その後 chloroform $5 \mathrm{cc}$ を加えて振盪後遠沈し，水層を捨て，2 ccの distilled water にて 3 回洗涤し遠沈後, 水層は捨てて chloroform 層のみを取る. 尚 sodium bicarbonate は, 可成り過剩に加 えても, pH8.5程度の弱アルカリであるので, aldosterone diacetateには変化を来たさない. 尚, distribution に際して, sodium bicarbonate を使用した上記の方法以外に，1/10N, NaOH distilled water のみにて試 みた成績は Fig. 5 亿示す如くである。即ち 1/10N NaOH では約 $90 \%$ 近くが除去出来るが， $\mathrm{pH} 11$ 程度の強 アルカリの為, aldosterone diacetate 亿変化がくる可能性がある. 又 distilled water のみでは60\%程度の

Fig. 4. Principle of distribution

(1) $\mathrm{R}-\mathrm{OH}+\underset{\mathrm{CH}_{3} \mathrm{CO}}{\mathrm{CH}_{3} \mathrm{CO}}>\mathrm{O} \underset{\text { Pyridine }}{\mathrm{R}-\mathrm{O} \mathrm{COCH}_{3}+\mathrm{CH}_{3} \mathrm{COOH}}$

(2) $\mathrm{CH}_{3} \mathrm{CO}$

$\mathrm{CH}_{3} \mathrm{CO}>\mathrm{O}+\mathrm{H}_{2} \mathrm{O}=2 \mathrm{CH}_{3} \mathrm{COOH}$

(3) $\mathrm{CHCOOH}+\mathrm{NaHCO}_{3}=\mathrm{CH}_{3} \mathrm{COONa}-\mathrm{H}_{2} \mathrm{O}+\mathrm{CO}_{2}$
Fig. 5. Comparison on the elimination of 1. $\mathrm{C}^{14}$ acetic anhydride under the various conditions for distribution.

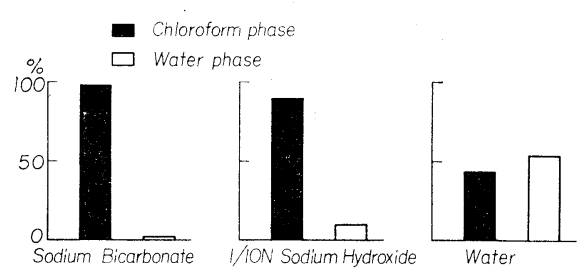


Fig. 6. Comparison of infrared absorptionspectrum between aldosterone and aldosterone diacetate

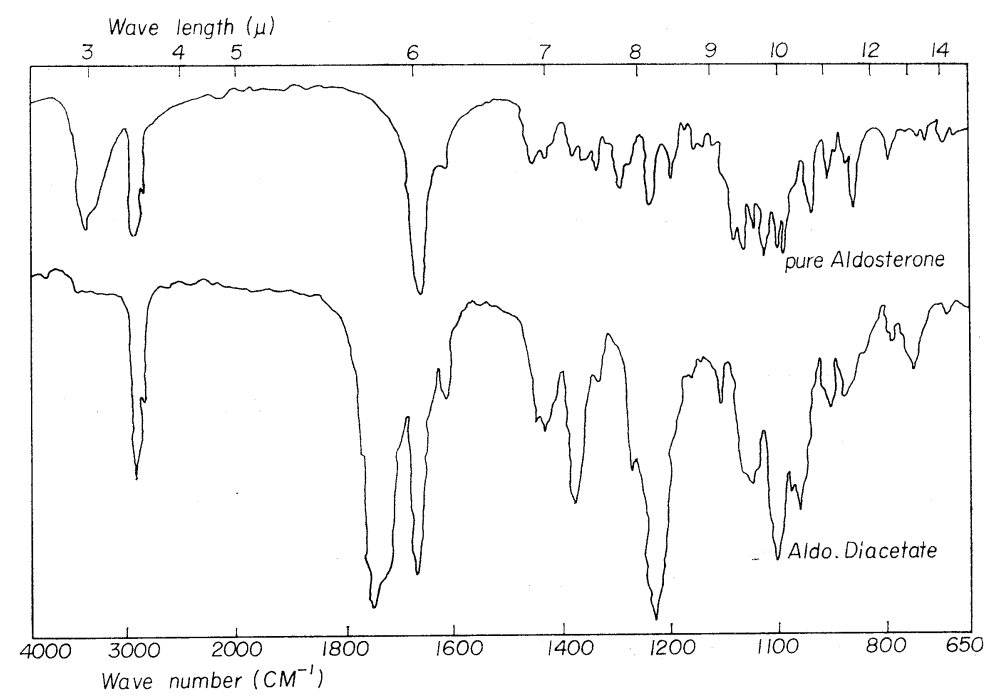

除去であつた，次に以上述べた方法にて pure aldosterone を acetylate し，ての acetylation products Infra-Red-Spectra にて検討した(Fig. 6). Fig. 6 では, pure aldosterone と acetylation products を比 較対照して示した。 即ち, pure aldosterone に認められる $3400 \mathrm{CM}^{-1}$ のOHの吸収は, acetylation products には認められず。 $2900 \mathrm{CM}^{-1}$ の $\mathrm{CH}$ の吸収は，共に認められており， acetylation products には， 1730 1760GM-1 亿 acetyl 基の吸収が認められ，1650GM-1の炭素の共扼二重結合の吸収は共に存在し，更 に 1230CM-1 の acetylation による G-O-C のエーテル結合の吸収も, acetylation products には認めら れる。このように pure aldosterone は，上記の方法により完全に aldosterone diacetate に転換したと考え られる，次に以上述べた方法で得た aldosterone diacetate の単離を企てるため，T.L.C.にて展開する必要が あるが，前述の分配操作で除去され得なかつた可能性のある僅かのI . $\mathrm{C}^{14}$ 酢酸，又は酢酸ソーダを，aldosterone diacetate の単離のための T.L.C. 展開時に

完全に取り除くことが望ましい。この様な見地から， 種々の T.L.C. system について検討したが，Fig.7 に示す如く，酢酸に極性を示すT.L.C. system は発 見されなかつた。しかし，比較的 system A 亿於て， aldosterone diacetate と一致する部分に $\mathrm{C}^{14}$ が少 ないので，乙れを採用した。尚，acetylation 後の $\mathrm{H}^{3} / \mathrm{C}^{14}$ ratio は, 1 回(system $\mathrm{A}$ )の展開では $8: 1$, 2 回 (system A+system E), 3 回 (System A+ system E+system D) では各々 10：1 と一定の $\mathrm{H}^{3} / \mathrm{C}^{14}$ ratio を示した。 との結果より著者は，acetylation 後の T.L.C 展開は, system A, Eの 2 回 でほぼ満足すべきと考えた。

iv) Counting

最終展開に於て aldosterone diacetate とRf值が 一致する部分をかき取り， methanol にて溶出後,
Fig. 7. Comparison on the development of $1 . \mathrm{C}^{14}$ acetic anhydride under the various systems of T.L.C.
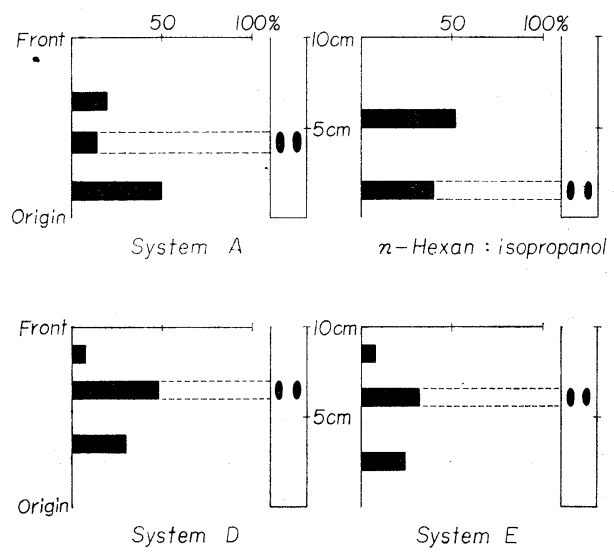
$20 \mathrm{ml}$ counting vial に取り，窒素ガスにて蒸発乾固後, Liquid Scintillation Counter にて channel ratio 法により測定した。測定条件は, monitor voltage 1400 volt, analyzer voltage 1350 volt, discriminator voltage は $\mathrm{L}_{2} 1.6$ volt, $\mathrm{L}_{3} 1.9$ volt にて測定した. 尚計算式は Kliman \& Peterson の式に準じた.

\section{測 定 成 績}

測定值は Table 1 亿示す如く，rat 1 匹につき24時間尿中 aldosterone 排泄量は，0.01〜0.06 $\mu$ g であつ た. Schwartz $\left.{ }^{14}\right)$ (1964)一派は 5 匹の rat を一群とし，Kliman \& Peterson の方法にて測定し 0.045〜0.07

Table 1. Aldosterone values of each samples

Urinary aldosterone excretion in rats

\begin{tabular}{c|c|c|c}
\hline \multirow{2}{*}{\begin{tabular}{c|c} 
Number of Rats \\
Status
\end{tabular}} & \multicolumn{2}{|c}{ Aldosterone $\mu \mathrm{g} / \mathrm{day}$} \\
\hline 17 & normal & 0.03 & Range \\
\hline 25 & goldblatts rats (after $1 \sim 2 \mathrm{~W})$ & 0.107 & $0.01 \sim 0.06$ \\
\hline
\end{tabular}

Aldosterone values in adrenal venous blood of dogs

\begin{tabular}{c|c|c|c}
\hline \multirow{2}{*}{ Number of Samples } & \multirow{2}{*}{ Status } & \multicolumn{2}{|c}{ Aldosterone $\mu \mathrm{g} / \mathrm{ml}$} \\
\cline { 3 - 4 } & & Mean & Range \\
\hline 5 & normal & 0.016 & $0.013 \sim 0.018$ \\
\hline
\end{tabular}

Aldosterone production following the incubation of rat adrenal section

\begin{tabular}{c|c|c|c}
\hline \multirow{2}{*}{ Number of Samples } & Status & \multicolumn{2}{|c|}{$\mu \mathrm{g} / 100 \mathrm{mg}$ of adrenal weight/2hours } \\
\cline { 2 - 4 } & normal & Mean & Range \\
\hline 5 & 0.229 & $0.205 \sim 0.253$ \\
\hline
\end{tabular}

$\mu \mathrm{g} / \mathrm{day} / \mathrm{rat}$ と報告している. 犬の副腎静脈血では，0.013 0.018 $\mu \mathrm{g} / \mathrm{cc}$ であつた. Kliman \& Peterson は 0.008 0.053 $\mu \mathrm{g} / \mathrm{min}$. と報告している. rat 副腎では $0.205 \sim 0.253 \mu \mathrm{g} / 100 \mathrm{mg}$ adrenal weight $/ 2$ hours であ つた.

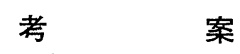

\section{i) Counting についての問題点}

放射能測定に際しての問題点は, 放射能崩壊による統計的誤差の他に, 測定効率がある. 殊に $\mathrm{H}^{3} の$ 場合 は $\mathrm{G}^{14}$ て比して $\beta$ 線のエネルギーが低いため, single photon phenomenon が起る可能性が多く, 乙の現象 は quenching が大きい程大である。 chemical quenching は測定試料調製の際の注意により, ある程度防 ぎ得るが，康色等の色素による quenching は，rat 尿採取の際䆏便混入する点からも，てれの完全な除去は 極めて困難であると思われる。 この点に関しては，Okita G.T. ${ }^{15)}$ (1956) 等が人尿について，尿色が $\mathrm{H}^{3}$ に対 して78〜100\%の quenching を示すととを報告している. 著者も rat 尿40ccの chloroform 抽出物が， 50 \%以上の quenching を示すととを確認した，著者の経験からも， double isotope dilution derivative method を尿中 corticosteroids の定量測定に応用するには， colour quenching の除去に今後尚一層の努 力と工夫を要するものと思われる。 instrument error も問題になるが, 著者は同一試料 3 回繰り返し測定 し，計数誤差が 5 \%以内になる様にした。 この様な instrument error と quenching error 合せると，20 
\%内外の誤差を考兵ねばならないが，乙れは動物実験の場合，許容される誤差範囲であると考える。

ii) 回収率について

全経過に於ける indicator (1-2-H $\mathrm{H}^{3}$ aldosterone) の回収率は約15〜20\%であつた. 尚 acetylation 前まで の回収率は平均80\%であつた。 TH. J. Benraad ${ }^{16)}$ (1965)等は, T.L.G と paper chromatography を併用し て行つた結果, 全回収率は約 $20 \%$ と報告している。

\section{結論}

以上私は T.L.C. と double isotope derivative dilution method を併用し, 更に distribution の過程で 独自の方法を考案し, 微量生体試料中の aldosterone の定量が可能であるととを確認した。 てれは Kliman \& Peterson に基づく従来の方法に比し, 更に正確迅速且つ簡便であり, 特に従来困難であつた微量生体試 料についての微細な変動も, 追求するてとが可能となり, 極めて有利な方法である.

本論文の要旨は昭和 40 年 4 月第 38 回日本内分泌学会総会にて発表した.

本稿を摖筆するにあたり御指導頂いた大島研三教授飞深謝し, 直接御教示を戴いた小田立男講師, 石井昭 郎講師に感謝すると共に日夜御協力を戴いた鈴木英生博士を始め当内科代謝班員各位に謝意を表します.

\section{文献}

1) UDENFRIEND, S. : J. Biochem. 187:65, (1950).

2) BOJESEN, E. \& DEGN, H. : Acta Endocrin., 37:541, (1961). $\quad 3$ ) AVIVI, P., SIMPSON, S.A., TAIT, J·F. : Proc. IInd Radioisotope Confer., vol. 1, Oxford, (1954). 4 4) AYRES, P.J. et al : J. Biochem., 65:639, (1957).

TAIT, J.F. et al : J. Clin. Invest., 40:72, (1961).

6) ULICK, S. : J. Biol. Chem., 236:680,(1961).

7) JONES, K.M. et al : Acta Endocrin., $30: 321$, (1959). $\quad$ 8) KLIMAN, B. \& PETERSON, R.

E. : J. Biol. Chem., 235:1639, (1960).

石井昭郎：日大医誌, 17:1710, (1958).

12）吉沢甚一郎：ホルモンと臨床，8：2，(1960)。

9）小田立男：日本医事新報，1729:37, (1957).

10)

Endocrin., 56, 523, (1955).

14) SChWARtZ, J., Velly, J. : Canad. Med. Assoc. J., 90:243,

(1964). 15) OKITA, G.T. : Nucleonics, $14: 76$, (1956).

16) TH. J. BENRAAD and

P.W.G. KLOPPENBORG : Clin. Chim. Acta., 12:565, (1965). 